\title{
Molecular Characterization of Vancomycin Resistance Enterococcusfaeciumclinical Isolates and Efficacy of Ozone on Pattern of Antibiotic(s) Resistance Bacterial Cell wall Using SEM.
}

\author{
Madiha A. Al-Enazi ${ }^{1}$,Alia A. Shoeib ${ }^{1 \& 2^{*}}$ \\ ${ }^{I}$ Department Of Botany And Microbiology, College Of Science, King Saud University, Saudi Arabia \\ ${ }^{2}$ DepartmentOf Plant Pathology, Faculty Of Agriculture, Alexandria University, Egypt.
}

\begin{abstract}
Sixty isolates ofVancomycin Resistant Enterococcus faecium (VRE) were collected from King Faisal Specialist Hospital in Riyadh, Saudi Arabia.These were collected from all clinical sample including surveillance cultures. Out of the 60 isolates, 21 isolates were subjected to multiplex polymerase chain reaction (MPCR) technique.Ten out of 21 isolates (47.6\%) carried a single vanA gene, while 6 isolates (28.6\%) had singlevanB gene. Rest of the isolates carried vanC (23.8\%) with either vanA (14.3\%) or vanB(9.5\%). The efficiency of ozone in converted of VRE isolated bacteria sensitivity from resistant to sensitive towards antibiotic(s) was recorded.Moreover, the effect of different flow rates of ozone $(2,4,6 \mathrm{~L} / \mathrm{min})$ on the cell wall of tested bacteria were observed by using Scanning Electron Microscope (SEM). The bacterial cells showed change, and some deformities in the external cell wall. In addition, some of bacterial cells showed early stage of cell lysis, as displayed lacking its integrity by forming bubble - like shape. Treatment with ozone led to decrease number of cells, comparison with non-treated cells.
\end{abstract}

Keywords: multiplex polymerase chain reaction; ozone; Scanning Electron Microscope;van genes; Vancomycin Resistant Enterococcus faecium;antibiotic(s).

\section{Introduction}

Since the researchers reported initial discoveryfrom patients in France and the UK in 1986 [1], Vancomycin Resistant Enterococcusfaecium (VRE)have been reported worldwide[2-8]. Conversely,many researchers reported that infections with VRE remained rare in many European hospitals [9-12].

E.faecium is an important nosocomial pathogen creating, serious limitations in treatment options because of cumulativeresistance to antimicrobial agents [13]. Enterococci are naturally resistant to many antibiotics including cephalosporin,aminoglycosides and clindamycin, and may also be resistant to tetracycline's and erythromycin. Three types of vancomycin resistance are found in enterococci; van $A$, vanB and vanC. van $A$ and vanBtype resistance accounts for most significant infections in clinical settings involving E. faecium and $E$. faecalis.vanC resistance is a low-level intrinsic resistance found naturally in rarer species of Enterococcus[14].

Multiplex PCR, pulsed-field gel electrophoresis (PFGE), polymerase chain reaction (PCR), the nanoplex PCR assay, hybridization of enterococcal plasmids with thevanA and vanBprobes, and sequencing of a fragment of $\operatorname{van} B$ were used in the analysis to distinguish between VRE with the $\operatorname{van} A, \operatorname{van} B, \operatorname{van} C, \operatorname{van} D$, vanE, and vanG genes[15-20].

The aim of this study to collect the samples of VRE, which exhibit resistant to antibiotics used for treatment, as well as, detection of genes that caused the resistance of bacteria to antibiotics using a multiplex PCR, besides influence of ozone on bacterial cell wall of VRE using Scanning Electron Microscope.

* Corresponding author: Alia A. Shoeib, Dept. of Plant Pathology, Faculty of Agriculture, Alexandria University, Egypt. e-mail: aliashoeib@alexu.edu.eg

\section{Materials and Methods}

Bacterial Isolates: A total number of 60 isolates of Vancomycin Resistant Enterococcusfaecium (VRE) from different patients were collected over a period from February to April 2009 from Microbiology laboratory in a hospital King Faisal Specialist (KFS), Microbiology Section, Riyadh, Saudi Arabia.

Identification of VRE Isolates: All isolates were grown on Blood Agar Base plates and analyzed by the Vitek automated system for species identification and antimicrobial susceptibility patterns. Bacterial isolates were then processed by the agar bilis-esculine screening, in the presence or absence of vancomycin $(6 \mu \mathrm{g} / \mathrm{ml})$, for enterococcal colonies and vancomycin resistance detection [16].

Antibiotic Sensitivity Tests: Disk diffusion method as reported by Kaçmaz and Aksoy[21] was used. Antibiotics [Vancomycin (VA), Ampicillin (AMP), Augmentin (AMC), Cefixime (CFM), Cefuroxime (CXM), Clindamycine (DA), Erythromycin (E), Gentamycin (GN), Levofloxacin (LEV), Cefoxitin (OFX), Amoxycilin- 
Clavulanic Acid (AML),Ciprofloxacine (CIP),Norfloxacin (NO), Nalidixic Acid (NA),Pipracllin (PN),Sulphamethoxazole (SXT),Nitrofurantoin (NF), Azithromycin (AZ) and Ceftriaxone (CRO)]effect was estimated by measuring the diameter of inhibition zone to determine the sensitivity and resistance of bacteria according to NCCLS [22].

Genetic Studies for Genes (vanA, vanB, vanC) detection: To extract DNA from bacteria using Kit (QIAGEN), the present steps were followed: Prepare an overnight culture on Nutrient Broth Medium. Harvest $1 \mathrm{ml}$ of bacterial cells in a micro-centrifuge tube by centrifuging for $10 \mathrm{~min}$ at $5000 \mathrm{xg}$ and discard supernatant. Re-suspend bacterial pellet in $180 \mu \mathrm{l}$ enzymatic lysis buffer. Incubate for at least $30 \mathrm{~min}$ at $37^{\circ} \mathrm{C}$. Add $25 \mu \mathrm{l}$ proteinase $\mathrm{K}$ and $200 \mu \mathrm{l}$ Buffer AL (without ethanol), then mix by overtaxing and incubated at $56^{\circ} \mathrm{C}$ for $30 \mathrm{~min}$. Add $200 \mu \mathrm{l}$ ethanol (96-100\%) to the sample, and mix thoroughly by overtaxing. Pipet the mixture (including any precipitate) into the DNeasy Mini spin column placed in a $2 \mathrm{ml}$ collection tube. Centrifuge at $6000 \mathrm{xg}$ for 1 min. Discard flow-through and collection tube. Place the DNeasy Mini spin column in a new $2 \mathrm{ml}$ collection tube, then, add $500 \mu \mathrm{l}$ Buffer AW1, and centrifuge for $1 \mathrm{~min}$ at $6000 \mathrm{xg}$. Discard flow-through and collection tube. Place the DNeasy Mini spin column in a new $2 \mathrm{ml}$ collection tube, add 500 $\mu 1$ Buffer AW2, and centrifuge for $3 \mathrm{~min}$ at 20,000xg to dry the DNeasy membrane. Discard flow-through and collection tube. Place the DNeasy Mini spin column in a clean $1.5 \mathrm{ml}$ micro-centrifuge tube, and pipette $200 \mu 1$ Buffer AE directly onto the DNeasy membrane. Incubate at room temperature for $1 \mathrm{~min}$, and then centrifuge for $1 \mathrm{~min}$ at $6000 \mathrm{xg}$ to elute [23].

Multiplex Polymerase chain reaction (MPCR)assays:All directly performed from the supernatant were obtained after the rapid DNA extraction method described above. The following steps were carried out as follow: An aliquot of $20 \mu \mathrm{L}$ of this supernatant was added to $80 \mu \mathrm{L}$ of a PCR mixture consisting of $1 \mathrm{X}$ reaction buffer $\left[16 \mathrm{mM}(\mathrm{NH} 4) 2 \mathrm{SO}_{4}, 67 \mathrm{mMTris}-\mathrm{HCl}(\mathrm{pH}\right.$ 8.8)], $0.2 \mathrm{mM}$ concentration of each of the four deoxyribonucleoside triphosphates (dATP, dCTP, dGTP and dTTP) (Promega Corp., Madison, WI), $2.5 \mathrm{mM}$ $\mathrm{MgCl} 2,50$ pmol of each Van primer and 4 pmol of each Ent primer, and $1.2 \mu 1$ ofTaq DNA polymerase. For each sample, the PCR reaction was performed with the Ent pair of primers to identify enterococcal isolates at the genus level and with the vanA, vanBandvanC pairs of primers to detect and differentiate the type of Vancomycin resistance. All MPCR assays were carried out with a negative control containing all of the reagents without DNA template. An initial denaturation step at $94^{\circ} \mathrm{C}$ for 2 min was followed by 25 cycles of amplification each consisting of $94^{\circ} \mathrm{C}$ for $60 \mathrm{~s}$, annealing at $55^{\circ} \mathrm{C}$ for $60 \mathrm{~s}$, and extension at $72^{\circ} \mathrm{C}$ for $60 \mathrm{~s}$, ending with a final extension step at $72^{\circ} \mathrm{C}$ for $5 \mathrm{~min}$. After PCR amplification, $5 \mu \mathrm{L}$ were removed and subjected to agarose gel electrophoresis (1.5\% agarose, $1 \mathrm{X}$ TBE, 100V) to estimate the size of the amplified products by comparison with a 1000-bp molecular size standard ladder. The gel was stained with ethidium bromide and the amplicons were visualized using a UV light box[23].

Effect of Antibiotics on Bacterial Growth Before and After its Exposure to Ozone: Tow isolates of VRE (E. faecium, NO.158-03001 and E. faecium, NO. 192-01264) were grown on Nutrient Broth suspension $100 \mathrm{~mL}$ and left for $24 \mathrm{~h}$ in incubator at $37^{\circ} \mathrm{C}$. Ozone stream was passed through a suspension of bacteria, as Flow rate $2 \mathrm{~L} / \mathrm{min}, 4 \mathrm{~L} / \mathrm{min}$ and $6 \mathrm{~L} / \mathrm{min}$ ozone for $20 \mathrm{~min}$. Ozone generators (Type/ 300000, Model/ 500M) was fed with pure oxygen, from an oxygen tank.

Electron Microscope Studies: Scanning Electron Microscope (SEM) was used to examine E. faecium (158-03001) and E. faecium (192-01264) isolates, before and after treated with ozone at Flow rate of 2, 4 and $6 \mathrm{~L} / \mathrm{min}$. Examine the bacterial cells by using JEOL JSM-6360LV SEM at magnification (15.000 X) and method of Afrikian et al. [24] was followed.

\section{Results}

Bacterial Isolates: Bacterial isolates of Vancomycin Resistant Enterococcus faecium (VRE) from different patients used in this study are shown in Table (I).

Identification of VRE Isolates: The 60 isolates of VRE which were grown on Blood Agar Base plates showed smooth, slightly domed colonies with $1-2 \mathrm{~mm}$ diameters. The isolates were found to be gram positive, cells spherical and occurring in pairs. All isolates were negative to catalase.

Detection of VRE in Isolates by Multiplex PCR amplification: The oligonucleotide primers used in this study are listed in Table (II) and were synthesized by QIAGEN GmbH - Germany.Using MultiplexPolymerase chain reaction (MPCR) technique, in this study was analyzed 21 Isolates of Vancomycin Resistant E. faecium (VRE), from patients of King Faisal Specialist hospital at Molecular Genetic Section.Gel electrophoresis of DNA fragments generated by MPCR amplification using Molecular weight marker (1000bp). The results were shown in Table (III), Figures (1) and (2).Some tested isolates E. faecium (VRE): (213-03328); (150-01521); (149-0862); (158-3001); (14-02293); (192-01264); (052-03936); (020-3516); (088-03320); (02402051); (233-0724); (305-01618); (307-02468) gave rise to a 732 bp PCR fragment corresponding to part of thevanAgene. 
Table I.Collected cases Vancomycin Resistant Enterococcus faecium (VRE) from King Faisal Specialist Hospital, Microbiology Department, Riyadh, Saudi Arabia over a period $21^{\text {st }}$ February to April 2009

\begin{tabular}{|c|c|c|c|c|}
\hline Date & Age/year & Sex & Clinical Sites & Isolates of Bacteria \\
\hline $21-02-2009$ & 68 & Male & Rectal swab & E. faecium (213-03328) \\
\hline 21-02-2009 & 49 & Female & Bile & E.faecium (150-01521) \\
\hline 29-02-2009 & 31 & Male & Stool (Anus) & E.faecium (149-00862) \\
\hline 29-02-2009 & $15 \mathrm{~m}$ & Male & Stool (Anus) & E. faecium (158-03001) \\
\hline 05-03-2009 & 31 & Male & Stool (Anus) & E. faecium (366-03615) \\
\hline 09-03-2009 & 19 & Female & Stool (colon) & E. faecium (015-012960) \\
\hline 14-03-2009 & $19 \mathrm{~m}$ & Male & Stool & E. faecium (014-02293) \\
\hline 15-03-2009 & 2 & Female & Stool & E. faecium (017-02975) \\
\hline 17-03-2009 & 12 & Male & Abdomen specify & E. faecium (052-03936) \\
\hline 17-03-2009 & $19 \mathrm{~m}$ & Male & Urine & E. faecium $(020-03516)$ \\
\hline 18-03-2009 & 12 & Male & Rectal swab & E. faecium (088-03320) \\
\hline 19-03-2009 & 2 & Female & Stool & E. faecium (024-02051) \\
\hline 20-03-2009 & $15 \mathrm{~m}$ & Male & Stool & E. faecium (028-01914) \\
\hline 20-03-2009 & 31 & Male & Anus & E. faecium (071-01085) \\
\hline 21-03-2009 & 12 & Female & Stool & E. faecium(231-03038) \\
\hline 21-03-2009 & 3 & Male & Stool & E. faecium(233-00724) \\
\hline 21-03-2009 & 12 & Female & Stool & E. faecium(234-02770) \\
\hline $22-03-2009$ & 6 & Male & Stool & E. faecium(238-02786) \\
\hline $22-03-2009$ & 8 & Male & Stool & E. faecium(276-01847) \\
\hline $22-03-2009$ & 15 & Male & Stool & E. faecium(276-03977) \\
\hline 23-03-2009 & 3 & Male & Stool & E. faecium(281-01009) \\
\hline $23-03-2009$ & 25 & Female & Stool & E. faecium(283-00502) \\
\hline 24-03-2009 & 3 & Male & Stool & E. faecium(284-02200) \\
\hline 24-03-2009 & 30 & Female & Stool & E. faecium(289-01055) \\
\hline 24-03-2009 & 31 & Male & Stool (Anus) & E. faecium(291-01710) \\
\hline 24-03-2009 & 48 & Female & Rectal swab & E. faecium(297-03537) \\
\hline 24-03-2009 & 25 & Female & Stool & E. faecium(305-01618) \\
\hline 24-03-2009 & 30 & Female & Stool & E. faecium (305-02627) \\
\hline $25-03-2009$ & 35 & Male & Abdomen specify & E. faecium(307-02468) \\
\hline $25-03-2009$ & 11 & Male & Stool & E. faecium $(308-02276)$ \\
\hline $26-03-2009$ & 11 & Male & Stool (Anus) & E. faecium(335-1529) \\
\hline 26-03-2009 & 53 & Male & Rectal swab & E. faecium (332-1649) \\
\hline 02-04-2009 & 48 & Female & Stool & E. faecium (339-4032) \\
\hline 09-04-2009 & $11 \mathrm{~m}$ & Male & Rectal swab & E. faecium (342-2349) \\
\hline 09-04-2009 & 3 & Male & Stool & E. faecium(244-3003) \\
\hline 09-04-2009 & 49 & Female & Abdomen specify & E. faecium (216-3034) \\
\hline 11-04-2009 & 19 & Female & Anus & E. faecium (184-1138) \\
\hline 11-04-2009 & 68 & Female & Stool & E. faecium $(180-3115)$ \\
\hline 13-04-2009 & 31 & Male & Anus & E. faecium (186-1988) \\
\hline $16-04-2009$ & 53 & Male & Urine & E. faecium (235-2745) \\
\hline 16-04-2009 & 49 & Female & Rectal swab & E. faecium (235-2757) \\
\hline 16-04-2009 & 2 & Female & Rectal swab & E. faecium (189-2121) \\
\hline 19-04-2009 & 51 & Female & Blood & E. faecium (192-01264) \\
\hline 19-04-2009 & 19 & Female & Stool & E. faecium (001-1122) \\
\hline 20-04-2009 & $15 \mathrm{~m}$ & Male & Stool & E. faecium (54-2456) \\
\hline 20-04-2009 & 31 & Male & Stool & E. faecium $(058-00795)$ \\
\hline $22-04-2009$ & 15 & Female & Stool (Anus) & E. faecium (110-01756) \\
\hline 24-04-2009 & 3 & Female & Urine & E. faecium (130-02157) \\
\hline 25-04-2009 & 80 & Male & Pleural Fluid & E. faecium (151-02621) \\
\hline $25-04-2009$ & $15 \mathrm{~m}$ & Male & Stool(Anus) & E. faecium (158-03001) \\
\hline $26-04-2009$ & 49 & Female & Abdomen specify & E. faecium (166-03387) \\
\hline 26-04-2009 & 3 & Female & Rectal swab & E. faecium (167-01933) \\
\hline 26-04-2009 & 49 & Female & Blood & E. faecium (172-03111) \\
\hline $27-04-2009$ & 2 & Female & Stool (Anus) & E. faecium (219-00841) \\
\hline $27-04-2009$ & 89 & Female & Stool & E. faecium (224-00449) \\
\hline $27-04-2009$ & 12 & Female & Blood & E. faecium (231-02232) \\
\hline 27-04-2009 & 31 & Male & Stool & E. faecium (199-03011) \\
\hline 29-04-2009 & 49 & Female & Rectal swab & E. faecium (235-02751) \\
\hline 29-04-2009 & 28 & Female & Stool & E. faecium (028-01914) \\
\hline 29-04-2009 & 35 & Female & Rectal swab & E. faecium(3392142) \\
\hline
\end{tabular}


Table II.Oligonucleotide primers used in the PCR reactions

\begin{tabular}{|l|l|l|l|l|}
\hline Gene & Primer & Sequence $\left(5^{\prime}-3^{\prime}\right)$ & $\begin{array}{l}\text { Size of PCR } \\
\text { product }(\mathrm{bp})\end{array}$ & Reference \\
\hline $\boldsymbol{v a n \boldsymbol { A }}$ & $\begin{array}{l}\text { A1 } \\
\text { A2 }\end{array}$ & $\begin{array}{l}\text { GGGAAAACGACAATTGC } \\
\text { GTACAATGCGGCCGTTA }\end{array}$ & 732 & {$[25]$} \\
\hline \multirow{2}{*}{$\boldsymbol{a n \boldsymbol { B }}$} & $\begin{array}{l}\text { B1 } \\
\text { B2 }\end{array}$ & $\begin{array}{l}\text { ATGGGAAGCCGATAGTC } \\
\text { GATTTCGTTCCTCGACC }\end{array}$ & 635 & {$[25]$} \\
\hline \multirow{2}{*}{$\boldsymbol{a n} \boldsymbol{C}$} & $\begin{array}{l}\text { C1 } \\
\text { C2 }\end{array}$ & $\begin{array}{l}\text { GGTATCAAGGAAACCTC } \\
\text { CTTCCGCCATCATAGCT }\end{array}$ & 822 & {$[25]$} \\
\hline
\end{tabular}

Table III.Presence (+) or absence (-) of genes ( $\operatorname{van} A, \operatorname{van} B, \operatorname{van} C)$ in tested isolates of Vancomycin Resistant E. faecium (VRE)

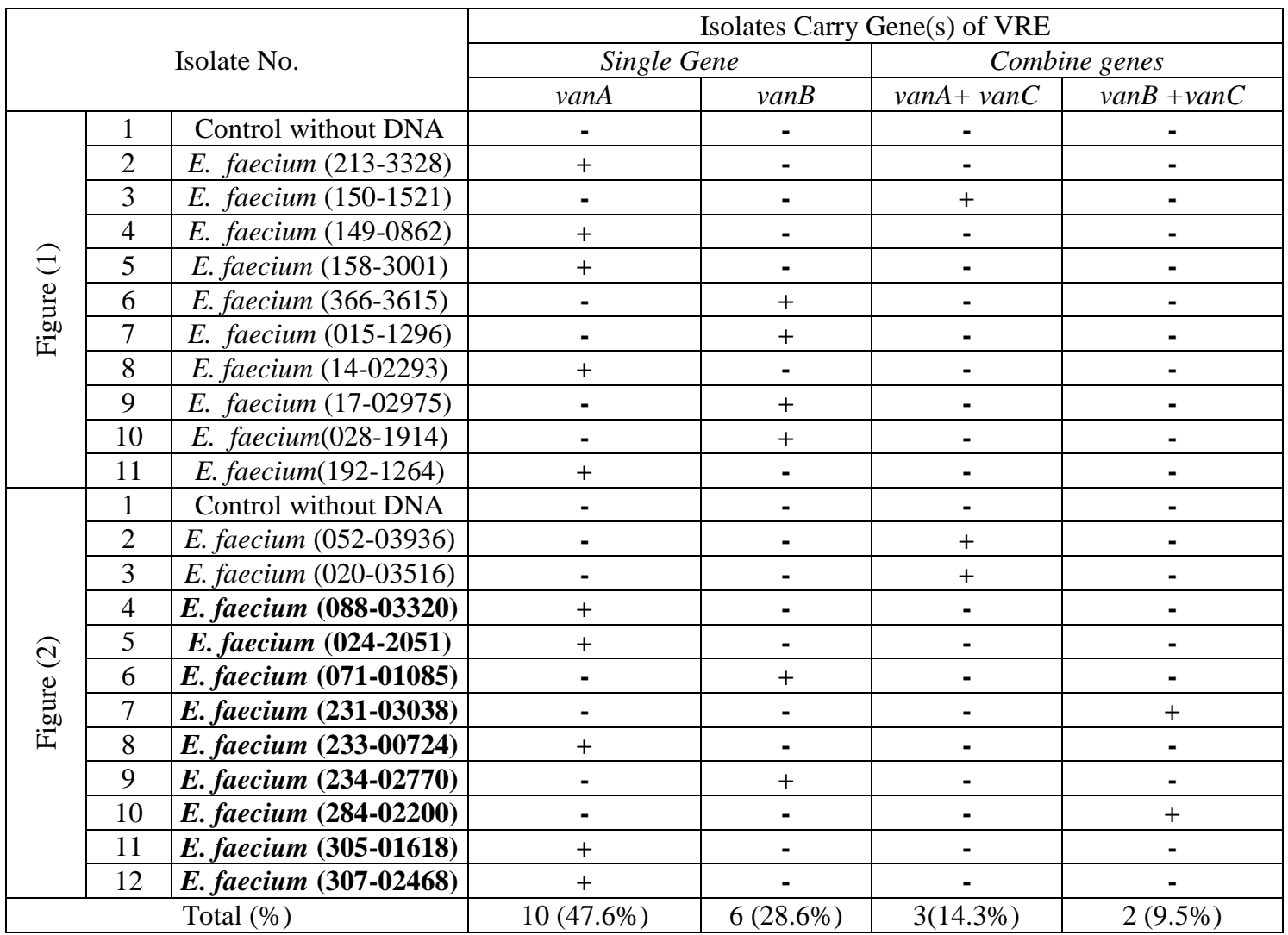

Tested isolates of E. faecium (366-3615); (015-1296); (17-02975); (028-1914); (017-01085); (23103038); (234-02770) and (284-02200); gave rise to a 635 bp PCR fragment corresponding to part of the vanB gene.Isolates of E. faecium (150-01521); (052-03936); (020-03516); (231-03038) and (284-02200) gave rise to an $822 \mathrm{bp} \mathrm{PCR} \mathrm{fragment} \mathrm{corresponding} \mathrm{to} \mathrm{part} \mathrm{of} \mathrm{the} \mathrm{vanC.} \mathrm{It} \mathrm{is} \mathrm{worth} \mathrm{mentioned} \mathrm{that} \mathrm{some} \mathrm{isolates} \mathrm{of} E$. faecium (150-1521); (052-03936) and (020-03516) was have vanA and vanC. Furthermore, vanB and vanC gene were detected in isolates (231-03038) and (284-02200).

Effect of Antibiotics on Bacterial Growth Before and After its Exposure to Ozone:

From Table (VI) was concluded as the following:Isolate (158-3001) was converted its sensitivity from resistant to sensitive towards antibiotics:AML, DA and GNafter ozone treatment at Flow Rate in $6 \mathrm{~L}, 6 \mathrm{~L}$ and $2 \mathrm{~L} / \mathrm{min}$ respectively.While, it maintains their resistance after ozone exposure, towards the following antibiotics: VA, AMP, CFM, CXM, E, LEV, OFX, AMC, CIP, NO, NA, PIP, SXT, NF, AZ and CRO.IsolateofVRE E. faecium (192-01264) became sensitive to GN after ozone treatment at Flow Rate in 2L/min.It maintains its resistance, after ozone exposure, towards the rest of tested antibiotics. 


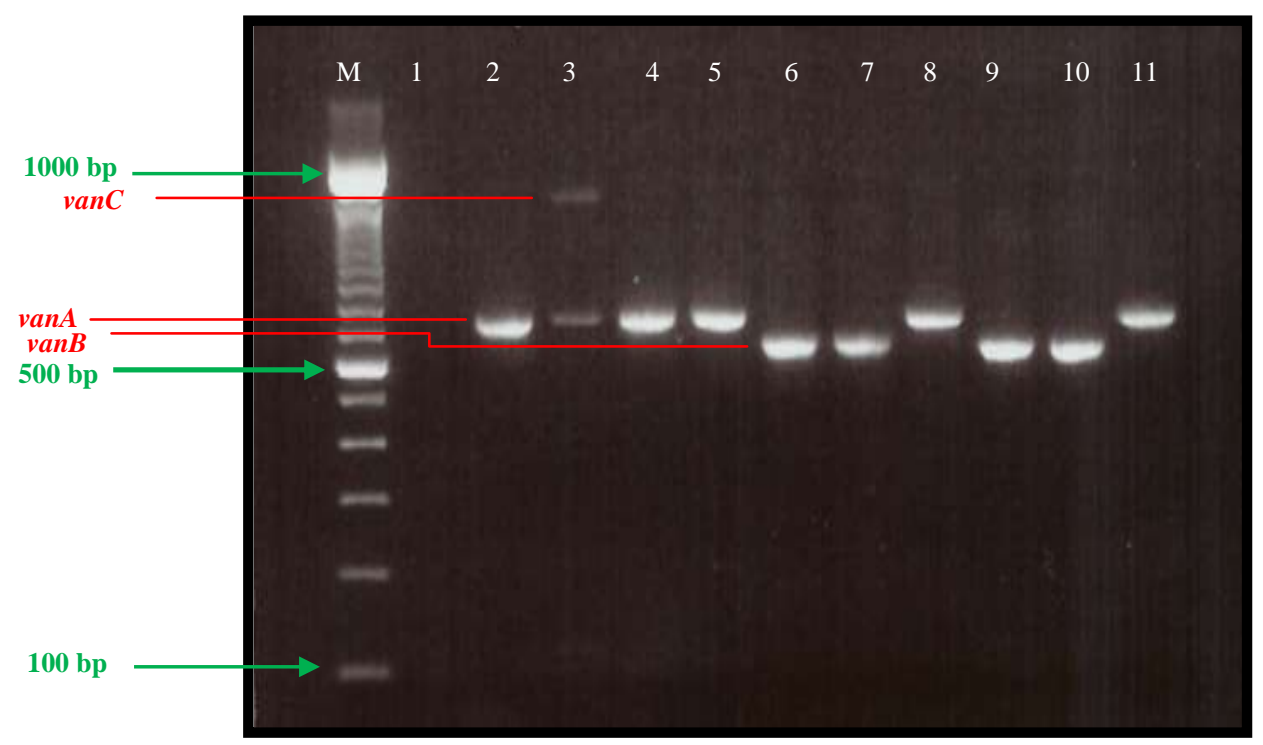

Fig. (1) Gel electrophoresis of DNA fragments generated by MPCR amplification. M, Molecular weight marker (1000bp). Lanes 1, Control without DNA ; 2, VRE 213-03328 (vanA) ; 3, VRE 150-01521 (vanA,vanC); 4, VRE 149-0862 (vanA); 5, VRE 158- 3001 (vanA); 6, VRE 366-3615 (vanB); 7, VRE 015-1296 (vanB); 8, VRE 1402293 (vanA); 9, VRE 17-02975 (vanB); 10, VRE 028-1914 (vanB) ; 11, VRE 192-01264(vanA). The electrophoresis was run in a $2 \%$ agarose gel, which was stained with ethidium bromide.

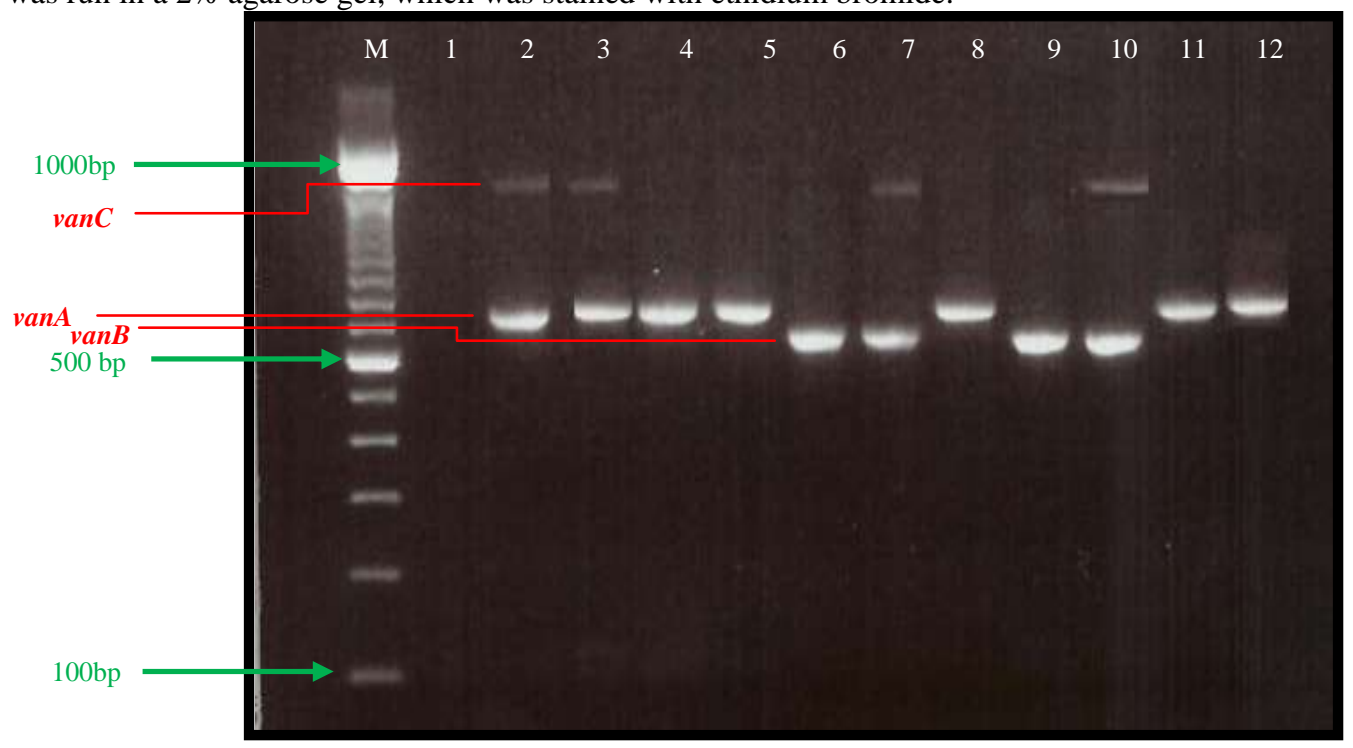

Fig. (2) Gel electrophoresis of DNA fragments generated by MPCR amplification. M, Molecular weight marker (1000bp). Lanes 1, Control without DNA; 2, VRE 052-03936 (vanA, vanC); 3, VRE 20-03516 (vanA,vanC); 4, VRE 088-03320 (vanA); 5, VRE 024-02051 (vanA); 6, VRE 017-01085 (vanB); 7, VRE 231-03038 (vanB, vanC); 8, VRE 233-00724 (vanA); 9, VRE 234-02770 (vanB); 10, VRE 284-02200 (vanB, vanC); 11, VRE 305-01618 (vanA); 12, VRE 307-02468 (vanA).The electrophoresis was run in a $2 \%$ agarose gel, which was stained with ethidium bromide.

Effect of Ozone on VRE Cells by Scanning Electron Microscope (SEM): SEM was used to examine E. faecium (158-03001) and E. faecium(192-01264), before and after treated with ozone at Flow rate of 2, 4, 6 L/min. The scanning electron micrograph of the isolate E. faecium(158-03001) before treated with ozone was normal spherical cells and some cells showed binary fission, Figure (3a).After the treatment of ozone on 2,4 and $6 \mathrm{~L} / \mathrm{min}$, observed change and damage to surface morphology and some deformities in the external shape and the beginning out of the cell contents as well as decreasing number of the cell, in Figs. $3 b, 3 c$, and $3 d$, in compared with non-treated cells.

The scanning electron micrograph of the isolate (192-01264) before treated with ozone was normal spherical cells, Fig. (4a). After treatment of ozone on $2 \mathrm{~L} / \mathrm{min}$ showed no change in external shape but it noticed that decreasing of bacterial cells number (Fig. 4b). After treatment of ozone on 4 and $6 \mathrm{~L} / \mathrm{min}$ the cell showed a 
Molecular Characterization of Vancomycin Resistance EnterococcusfaeciumClinical

distortion in the form of the cell and in the beginning out of the cell contents and also decreasing bacterial cells number (Figs. 4c and 4d).

Table IV.

Effect of antibiotics on bacterial growth before and after exposure to ozone.

\begin{tabular}{|c|c|c|c|c|c|c|c|c|c|c|c|c|c|c|c|c|c|c|c|c|}
\hline 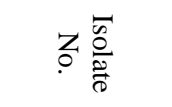 & 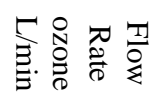 & $\underset{>}{\triangleright}$ & 桑 & 芳 & 骎 & $x$ & $\underset{D}{\ominus}$ & $\pi$ & $\Omega$ & 莲 & $\begin{array}{l}0 \\
\substack{1 \\
x}\end{array}$ & 党 & $\Theta$ & ż & $\underset{D}{Z}$ & $\nabla$ & $\mathscr{x}$ & 恐 & R & $\pi$ \\
\hline \multirow{4}{*}{$\begin{array}{l}\text { E. faecium } \\
(158-03001)\end{array}$} & control & $\mathrm{R}$ & $\mathrm{R}$ & $\mathrm{R}$ & $\mathrm{R}$ & $\mathrm{R}$ & $\mathrm{R}$ & $\mathrm{S}$ & $\mathrm{R}$ & $\mathrm{R}$ & $\mathrm{S}$ & $\mathrm{S}$ & $\mathrm{S}$ & $\mathrm{S}$ & $\mathrm{S}$ & $\mathrm{S}$ & $\mathrm{R}$ & $\mathrm{S}$ & $\mathrm{R}$ & $\mathrm{R}$ \\
\hline & $2 \mathrm{~L} / \mathrm{min}$ & $\mathrm{R}$ & $\mathrm{R}$ & $\mathrm{R}$ & $\mathrm{R}$ & $\mathrm{R}$ & $\mathrm{R}$ & $\mathrm{S}$ & $\mathrm{S}$ & $\mathrm{R}$ & $\mathrm{S}$ & $\mathrm{S}$ & $\mathrm{S}$ & $\mathrm{S}$ & $\mathrm{S}$ & $\mathrm{S}$ & $\mathrm{R}$ & $\mathrm{S}$ & $\mathrm{R}$ & $\mathrm{R}$ \\
\hline & $4 \mathrm{~L} / \mathrm{min}$ & $\mathrm{R}$ & $\mathrm{R}$ & $\mathrm{R}$ & $\mathrm{R}$ & $\mathrm{R}$ & $\mathrm{R}$ & $\mathrm{S}$ & $\mathrm{S}$ & $\mathrm{R}$ & $\mathrm{S}$ & $\mathrm{S}$ & $\mathrm{S}$ & $\mathrm{S}$ & $\mathrm{S}$ & $\mathrm{S}$ & $\mathrm{R}$ & $\mathrm{S}$ & $\mathrm{R}$ & $\mathrm{R}$ \\
\hline & $6 \mathrm{~L} / \mathrm{min}$ & $\mathrm{R}$ & $\mathrm{R}$ & $\mathrm{S}$ & $\mathrm{R}$ & $\mathrm{R}$ & $\mathrm{S}$ & $\mathrm{S}$ & $\mathrm{S}$ & $\mathrm{R}$ & $S$ & $\mathrm{~S}$ & $\mathrm{~S}$ & $\mathrm{~S}$ & $\mathrm{~S}$ & $\mathrm{~S}$ & $\mathrm{R}$ & $\mathrm{S}$ & $\mathrm{R}$ & $\mathrm{R}$ \\
\hline \multirow{4}{*}{$\begin{array}{c}\text { E. faecium } \\
(192-01264)\end{array}$} & control & $\mathrm{R}$ & $\mathrm{R}$ & $\mathrm{R}$ & $\mathrm{R}$ & $\mathrm{R}$ & $\mathrm{R}$ & $\mathrm{S}$ & $\mathrm{R}$ & $\mathrm{R}$ & $\mathrm{S}$ & $\mathrm{S}$ & $\mathrm{S}$ & $\mathrm{S}$ & $\mathrm{S}$ & $\mathrm{S}$ & $\mathrm{R}$ & $\mathrm{S}$ & $\mathrm{R}$ & $\mathrm{R}$ \\
\hline & $2 \mathrm{~L} / \mathrm{min}$ & $\mathrm{R}$ & $\mathrm{R}$ & $\mathrm{R}$ & $\mathrm{R}$ & $\mathrm{R}$ & $\mathrm{R}$ & $\mathrm{S}$ & $\mathrm{S}$ & $\mathrm{R}$ & $\mathrm{S}$ & $\mathrm{S}$ & $\mathrm{S}$ & $\mathrm{S}$ & $\mathrm{S}$ & $\mathrm{S}$ & $\mathrm{R}$ & $\mathrm{S}$ & $\mathrm{R}$ & $\mathrm{R}$ \\
\hline & $4 \mathrm{~L} / \mathrm{min}$ & $\mathrm{R}$ & $\mathrm{R}$ & $\mathrm{R}$ & $\mathrm{R}$ & $\mathrm{R}$ & $\mathrm{R}$ & $\mathrm{S}$ & $\mathrm{S}$ & $\mathrm{R}$ & $\mathrm{S}$ & $\mathrm{S}$ & $\mathrm{S}$ & $\mathrm{S}$ & $\mathrm{S}$ & $\mathrm{S}$ & $\mathrm{R}$ & $\mathrm{S}$ & $\mathrm{R}$ & $\mathrm{R}$ \\
\hline & $6 \mathrm{~L} / \mathrm{min}$ & $\mathrm{R}$ & $\mathrm{R}$ & $\mathrm{R}$ & $\mathrm{R}$ & $\mathrm{R}$ & $\mathrm{R}$ & $\mathrm{S}$ & $\mathrm{S}$ & $\mathrm{R}$ & $S$ & $\mathrm{~S}$ & $\mathrm{~S}$ & $\mathrm{~S}$ & $\mathrm{~S}$ & $\mathrm{~S}$ & $\mathrm{R}$ & $\mathrm{S}$ & $\mathrm{R}$ & $\mathrm{R}$ \\
\hline
\end{tabular}

* R: Resistant. * S: Sensitive. *I: Intermediate (VA): Vancomycin. (AMP): Ampicillin. (AMC): Augmantin. (CFM): Cefixime. (CXM): Cefuroxime. (DA): Clindamycine. (E): Erythromycin. (GN): Gentamycin. (LEV): Levofloxacin. (OFX): Cefoxitin. (AML): Amoxycilin-Clavulanic Acid. (CIP): Ciprofloxacine. (NO): Norfloxacin. (NA): Nalidixic Acid. (PN): Pipracllin. (SXT): Sulphamethoxazole. (NF): Nitrofurantoin. (AZ): Azithromycin. (CRO): Ceftriaxone.

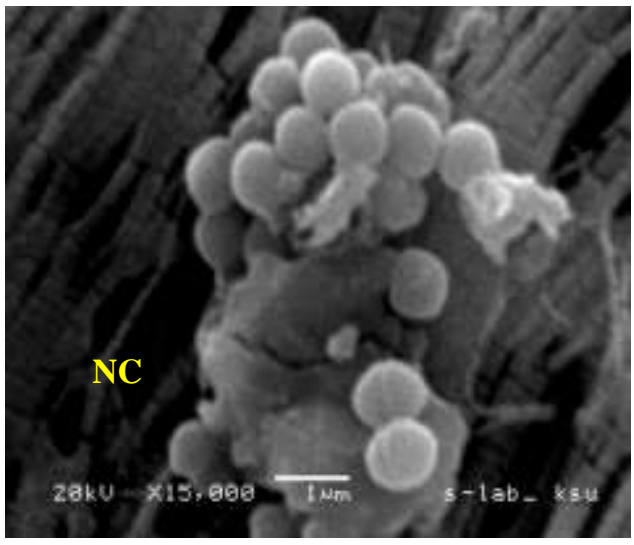

(a)

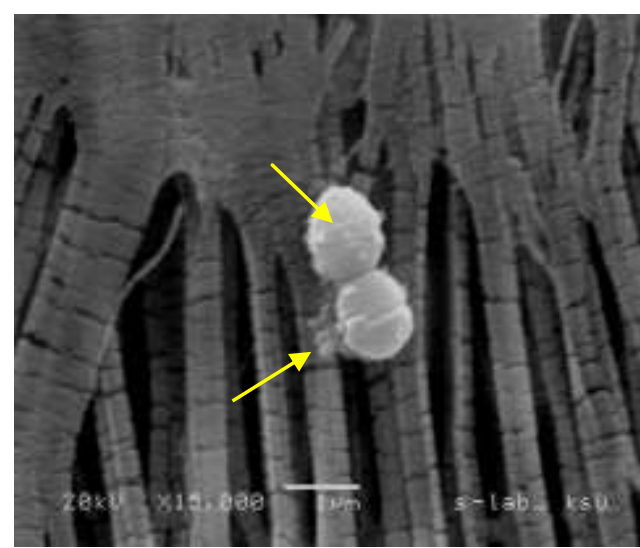

(c)

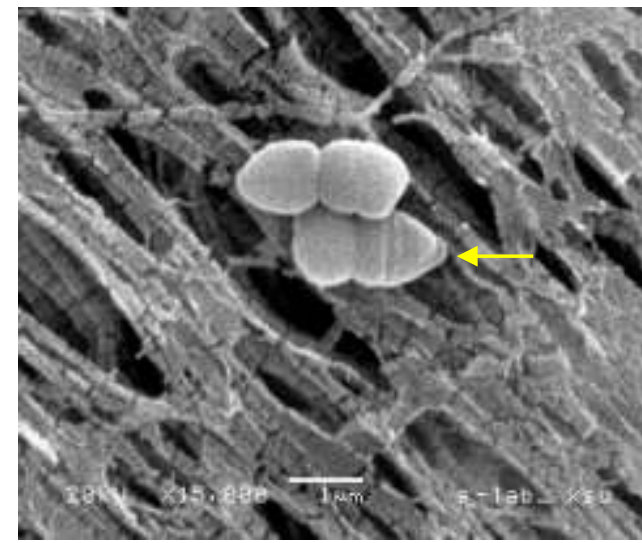

(b)

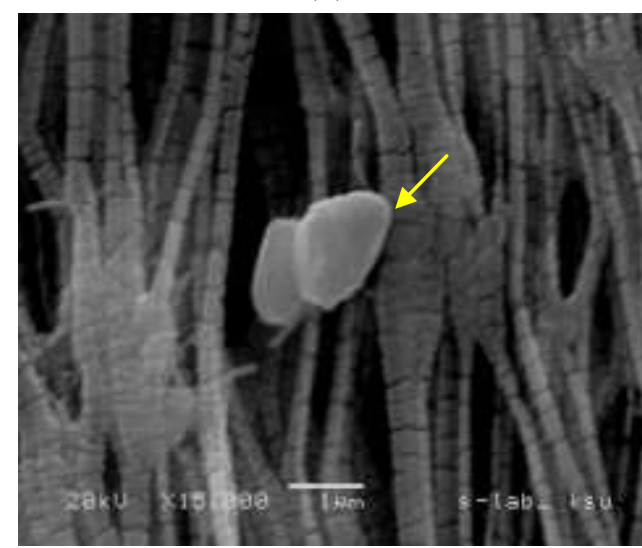

(d)

Figure (3): Scanning electron micrograph of E. faecium VRE (158-03001-Stool, Anus) treated with ozone, (a): Normal cell (NC) of control showed spherical cells and some cells showed binary fission. (b-c-d): Bacterial cells treated with ozone for 2,4 and $6 \mathrm{~L} / \mathrm{min}$ respectively, showed Oval shape, decreasing numbers of cells, also (b-c): cells showed the beginning out of the cell contents and (b-d): start of collapsed of cell component and cell deformity(arrows). 


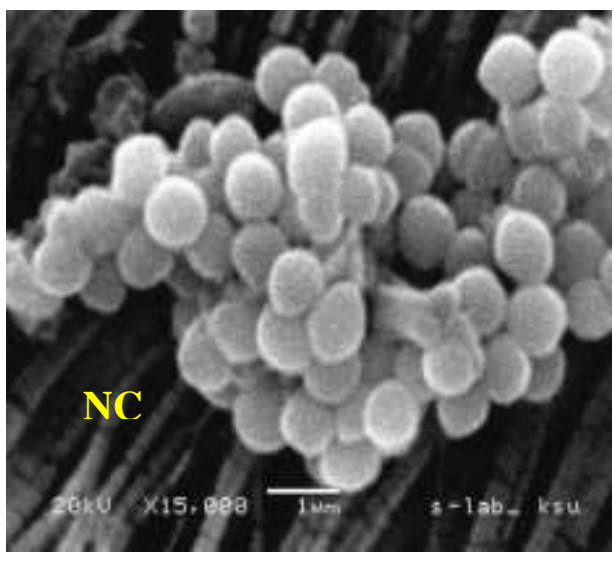

(a)

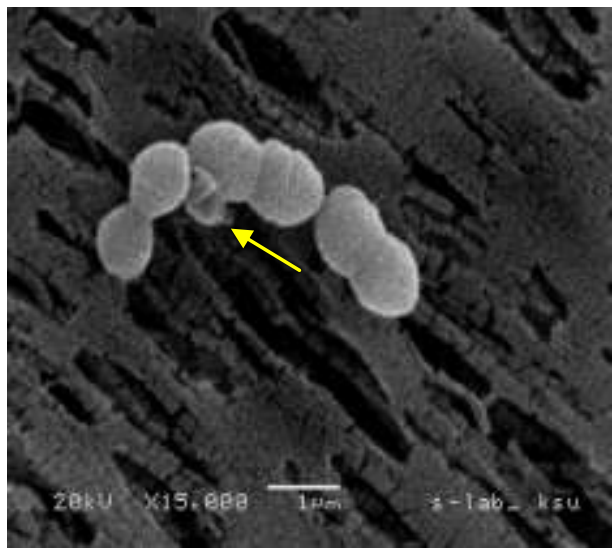

(c)

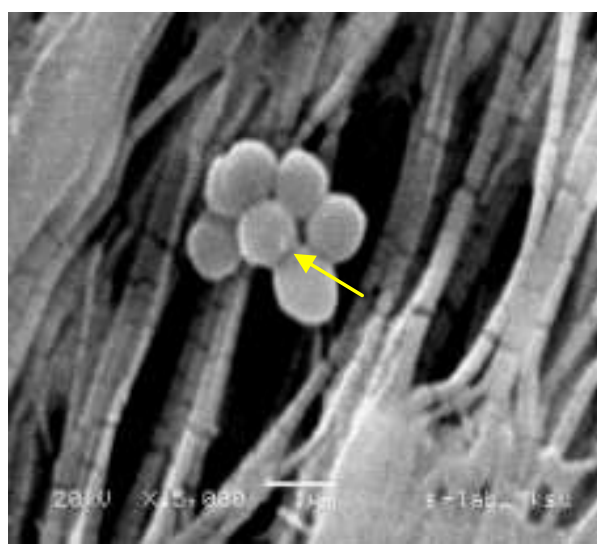

(b)

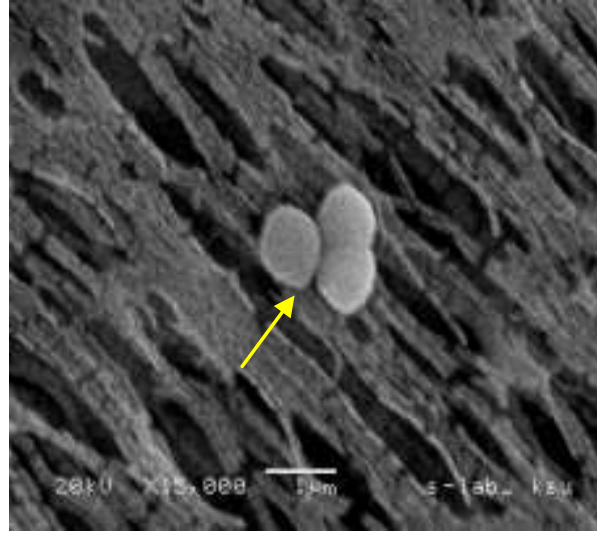

(d)

Figure (4): Scanning electron micrograph ofIsolate E. faecium (192-01264- Blood) treated with ozone. (a): Normal cell $(\mathrm{Nc})$ of control showed spherical cells. (b-c-d): Bacterial cells treated with ozone for 2,4 and 6 $\mathrm{L} / \mathrm{min}$ respectively, showed Oval shape, decreasing numbers of cells as well as cell deformity,also (c) cells showed the beginning out of the cell contents (arrows).

\section{Discussion}

A Multiplex Polymerase Chain Reaction (MPCR) protocol was designed in this study, for the simultaneous identification and detection of VancomycinResistanceE. faecium(VRE) isolates. Results obtained declared that out of $21 \mathrm{VRE}$ isolates, 13 was have vanA gene, the percentage was $61.9 \%$. Also, the results showed the rest of the isolates (8isolates) containing $\operatorname{vanB}(38.1 \%)$ as well as 5 isolates $(23.8 \%)$ were carried vanC with either vanA or vanB (14.3, 9.5\% respectively).Presentresults confirmed that the MPCR technique was effective, applicable, practical and easy to detect gene(s) in VRE isolates. Perez-Hernandezet al.[16], who found that the MPCR assay is essential for the identification of the most common Enterococcussp.

ExposureVREcells for the ozone led to switch theirresistance towards some antibiotics (AML, DA and GN) to sensitive,but not vice versa. The same results were achieved by Shoeib and Al-Obiri[26] who found none of sensitive isolates of high vaginal swab (HVS) were mutated to antibiotic(s) resistant after exposure to the tested ozone level(s).

The influence of ozone level(s)on the surface morphology in the external shape of VREcells, either from clinical sites stool or clinical sites Blood,led to damage,some deformities, decreasing number of the bacterial cells, as well as, the beginning out of the cell contents. This result is in arrangement with Thanomsubet. al.[27] who found ultrastructural changes and damage to surface morphology in Gram-positive bacteria. The most cited explanation for ozone's bactericidal effects centers on disruption of envelope integrity through peroxidation of phospholipids and lipoproteins [28]. There is evidence for interaction with proteins as well amino acids [29].

The mechanism of resistance of Enterococci to Vancomycin is mediated by nine distinct vancomycin resistance clusters have been described in enterococci (vanA, vanB, vanC, vanD, vanE, vanG, vanL, vanMandvanN) [30-33]. The genes associated with high level VR in Enterococci, vanA, vanB, and vanC. There encodes a ligase responsible for the synthesis of the depsipeptide D-alanyl-D-lactate which is incorporated into a 
pentapeptide peptidoglycan cell wall precursor to which Vancomycin binds poorly. In contrast, in Vancomycinsusceptible cells, Vancomycin complexes with the D-alanyl- D-alanine termini of normal pentapeptide peptidoglycan cell wall precursor thereby inhibiting cell wall synthesis [34]. Although present results disclosed that VRE isolates were maintained their resistance to vancomycin after exposure to the tested level(s) of ozone, but efficiency of ozone in loss tested isolates for their resistance of certain antibiotic(s), could be considered a positive trait for using ozone therapy with increase its level in combined with antibiotic(s).

\section{Literature}

[1]. Uttley AH, Collins CH, Naidoo J(1988)Vancomycin-resistant enterococci. Lancet 57-8

[2]. Woodford N (2001) Epidemiology of the genetic elements responsible for acquired glycopeptide resistance in enterococci. Microb Drug Resist 7: 229-34

[3]. Klare I, Konstabel C, Badstübner D, Werner G, Witte W(2003) Occurrence and spread of antibiotic resistance in Enterococcusfaecium. Int J Food Microbiol 88: 269-290

[4]. Lee K, Jang SJ, Lee HJ, Ryoo N, Kim M, Hong SG (2004) Increasing prevalence of vancomycin-resistant Enterococcus faecium, expanded-spectrum cephalosporin-resistant Klebsiellapneumoniae, and imipenem-resistant Pseudomonas aeruginosa in Korea: KONSAR study in 2001. J Korean Med Sci 19:8-14

[5]. Leavis L, Bonten J,Willems J(2006) Identification of high-risk enterococcal clonal complexes: global dispersion and antibiotic resistance. CurrOpinMicrobiol 9: 454-60

[6]. Borgmann S, Schulte B, Wolz C, Gruber H, Werner G, Goerke C, Klare I, Beyser K, Heeg P,Autenrieth IB(2007) Discrimination between epidemic andnon-epidemic glycopeptideresistantE. faecium in a post-outbreak situation. J Hospital Infection 67: 49-55

[7]. Yoon YK, Sim HS, Kim JY, Park DW, Sohn JW, Roh KH, Lee SE, Kim MJ(2009) Epidemiology and Control of an Outbreak of Vancomycin-Resistant Enterococci in the Intensive Care Units. Yonsei Med J50 (5): 637-643

[8]. Phukan C, Lahkar M, Ranotkar S,Saikia KK(2016) Emergence of vanA gene among vancomycin-resistant enterococci in a tertiary care hospital of North - East India. Indian J Med Res143: 357-361. DOI:10.4103/0971-5916.182627

[9]. Basustaoglu A, Aydogan H,Beyan C(2001) First glycopeptide-resistant Enterococcus faecium isolate from blood culture in Ankara, Turkey. Emerg Infect Dis 7:160-1

[10]. Colak D, Naas T, Gunseren F, Fortineau N, Ogunc D, Gultekin M,Nordmann P(2002) First outbreak of vancomycin- resistant enterococci in a tertiary hospital in Turkey. J Antimicrob Chemo ther 50:397-401

[11]. Stampone L, Grosso MD, Boccia D,Pantosti A(2005) Clonal Spread of a Vancomycin-Resistant Enterococcus faecium Strain among Bloodstream-Infecting Isolates in Italy. J ClinMicrobiol 43(4): 1575-1580

[12]. Ergani-Ozcan A, Naas T, Baysan BO, Ogunc D, Inan D, Colak D,Nordmann P(2008) Nosocomial outbreak of vancomycinresistant Enterococcus faecium in a pediatric unit at a Turkish university hospital. J AntimicrobChemother61(5):1033-1039

[13]. Murray BE (2000)Vancomycin-resistant enterococcal infections. NEng J Med 342:710

[14]. NHMRC: National Health and Medical Research Council. 1996. Emergence of Vancomycin Resistant Enterococci in Australia. Commonwealth Department of Health and Family Services, Commonwealth of Australia

[15]. Suppola JP, Kolhho E, Salmenlinna S, Tarkka E, Vuopio-Varkila J,Vaara M(1999)vanA and vanB Incorporate into an Endemic Ampicillin-Resistant Vancomycin-Sensitive Enterococcus faecium Strain: Effect on Interpretation of Clonality. J ClinMicrobiol37(12): 3934-3939

[16]. Perez-Hernandez X, Mendez-Alvarez S, Claverie-Martın F(2002) A PCR assay for rapid detection of vancomycin-resistant enterococci. DiagnMicrobiol Infect Dis42: 273-277

[17]. Hanaki H, Yamaguchi Y, Nomurac S, NagayamadA,Sunakawa K(2004) Rapid detection and differentiation method of VanA,VanBVanC phenotypes in vancomycin-resistant enterococci. Int J Antimicrob Agents23: 502-505

[18]. Domingo MC, Huletsky A, Giroux R, Boissinot K, Picard FJ, Lebel P, Ferraro MJ,Bergeron MG(2005) High prevalence of glycopeptide resistance genes $v a n B$, vanD, and $v a n G$ not associated with enterococci in human fecal flora. Antimicrob Agents Chemother49 (11): 4784-4786DOI:10.1128/AAC

[19]. Yean CY, Yin LS, Lalitha P,Ravichandran M(2007) A nanoplex PCR assay for the rapid detection of vancomycin and bifunctional aminoglycoside resistance genes in Enterococcusspecies. BMC Microbiology 7: 112

[20]. Ture M, Altinok I,Capkin E(2015) Comparison of pulsed-field gel electrophoresis and enterobacterial repetitive intergenic consensus PCR and biochemical tests to characterize Lactococcusgarvieae. J Fish Dis 38(1):37-47

[21]. Kaçmaz B,Aksoy A (2005) Antimicrobial resistance of enterococci in Turkey. Int J Antimicrob Agents 25:535-538.

[22]. NCCLS: National Committee for Clinical Laboratory Standards (2003) Approved Standards M2-A8. Performance Standards for antimicrobial disk susceptibility test, $8^{\text {th }}$ ed. NCCLS, Wayne, pa

[23]. Palladino S, Kay ID, Flexman JP, Boehm I, Costa AMG, LambertEJ, Christiansen KJ(2003) Rapid Detection of vanA and vanB Genes Directly from Clinical Specimens and Enrichment Broths by Real-Time Multiplex PCR Assay. J ClinMicrobiol 41(6):24832486

[24]. Afrikian EG, JulianG, Bulla LA(1973) Scanning Electron Microscopy of Bacterial Colonies. ApplMicrobiol 26(6):934-937.

[25]. Dutka-Malen S, Evers S and Courvalin P (1995) Detection of glycopeptide resistance genotypes and identification to the species level of clinically relevant enterococci by PCR. J ClinMicrobiol33:24-27.

[26]. Shoeib AA, Al-Obiri KKH(2014) The effect of ozone on bacterial vaginosis and how it is affected by ultrastructural changes of cells by transmission electron microscope (TEM). Afr J Microbiol Res8(10):1060-1069

[27]. ThanomsubB, Anupunpisit V, Chanphetch S, Watcharachaipong T, Poonkhum R,Srisukonth C (2002) Effects of ozone treatment on cell growth and ultra-structural changes in bacteria.J Gen ApplMicrobiol 48(4):193-9

[28]. Stephen D (2000) Ozone Research Data. Dallas Massage Therapist.www.holisticbodyworker.com

[29]. Mudd JB, Leavitt R,Ongun A, McManus T (1969) Reaction of ozone with amino acids and proteins. Atmos Environ 3:669-682

[30]. Courvalin P (2006)Vancomycin resistance in gram-positive cocci. Clin Infect Dis 42: S25-34. Informative review of vancomycin resistance in enterococci

[31]. Boyd DA, Willey BM, Fawcett D,GillaniN,MulveyMR(2008) Molecular characterization of Enterococcus faecalis N06-0364 with low-level vancomycin resistance harboring a novel D-Ala-D-Ser gene cluster, vanL. Antimicrob Agents Chemother52:2667-72

[32]. Xu X, LinD, YanG, YeX, WuS, GuoY,ZhuD, HuF, ZhangY, WangF, JacobyGA,WangM(2010)vanM, a new glycopeptide resistance gene cluster found in Enterococcus faecium. Antimicrob Agents Chemother 54: 4643-7

[33]. Lebreton F, Depardieu F, Bourdon N, Fines-GuyonM, BergerP, CamiadeS, LeclercqR, CourvalinP, CattoirV(2011)D-Ala-dSerVanN-type transferable vancomycin resistance in Enterococcus faecium. Antimicrob Agents Chemother55:4606-12

[34]. Patel R (2003) Clinical impact of vancomycin-resistant enterococci. J Antimicrob Chemotherapy 51(Suppl S3):iii13-iii2 